\title{
Development of single-industry towns as factor of economic and regional growth
}

\author{
Gennadiy Rubtsov ${ }^{1, *}$ and Aleksandr Litvinenko ${ }^{2}$ \\ ${ }^{1}$ Alsel Joint Stock Company, St. Petersburg, Gakkelevskaya Street, 21, 197227 St. Petersburg, Russia \\ ${ }^{2}$ St. Petersburg University of the Ministry of Internal Affairs of Russia, Letchika Pilyutova Street, 1, \\ 198206 St. Petersburg, Russia
}

\begin{abstract}
Single-industry towns occupy a special place in the system of regional economic development of Russia. To date, domestic practice has accumulated significant experience in the management of mono-profile areas. In fact, its own model of mono-education management, which includes an individual set of tools for socio-economic impact, has been developed. The institute of development of single-industry towns was formed into a complete system of tested mechanisms and organizational forms of their implementation. The basic directions of support of monoprofile territories are defined, the bodies of development of singleindustry towns are created, the complex programs of development of monoformations are tested and adjusted. The process of development of mono-territories has passed to the "post-institutional" stage, when the system of institutions for single-industry towns management (SingleIndustry Towns Development Fund), tested in practice, has been subjected to scientific and public criticism, and to date is able to effectively generate a qualitatively different level of influence on the socio-economic situation of cities of the mono-profile type.
\end{abstract}

\section{Introduction}

The problem of single-industry towns in the Russian Federation today remains one of the most painful and complex. In 2020, there are 319 mono-profile entities in the Russian Federation, on the territory of which more than 15 million people live [1]. One in four cities in the country is considered mono-profile, and the share of products of city-forming enterprises located in single-city towns reaches $40 \%$ of domestic GDP [2]. In this case, the influence of mono-territories on the economic development of the Russian Federation as a whole is obvious. Federal authorities allocate significant funds for programs for the development of single-industry towns, and mechanisms for supporting and modernizing the economies of such territorial entities are being developed and borrowed from world practice. At the same time, the scientific and journalistic community characterizes the process of reducing the number of single-industry towns in the Russian Federation as extremely slow. In particular, from 2010 to 2019, the number of mono-profile municipalities decreased from 335 to 319 [1].

${ }^{*}$ Corresponding author: genadij.rubtzov@yandex.ru 
In addition, an unsatisfactory assessment of the development of single-industry towns was presented by the Accounts Chamber of the Russian Federation, which questioned the effectiveness of the existing mechanisms for supporting mono-profile entities. As the main shortcomings, attention was focused on the disintegration of the program with strategic national priorities - the creation of highly productive jobs, increasing the growth of labor productivity. Particular attention was paid to the survey of residents of single-industry towns, who mostly described the standard of living in the city as a crisis. The methodology for assessing the effectiveness of the program, used by the Ministry of Economic Development, was also questioned. Thus, the newly created jobs included temporarily employed citizens, which allowed them to double the planned figure at a higher average Russian unemployment rate in most mono-territories. The real number of investments in the development of single-industry towns was questionable. The planned indicator, which was almost 10 times exceeded, according to experts, was achieved by adding up all sources of funds in the mono-territory (including loans and funds of citizens for shared construction).

In turn, the analysis of the Federal Tax Service showed a decrease in entrepreneurial activity during the implementation of the development program for single-industry towns, where the number of liquidated enterprises consistently exceeded the number of newly created ones.

\section{Materials and Methods}

The research information base includes materials of various types: decrees, decrees of the Government of the Russian Federation, the Ministry of Economic Development of the Russian Federation, reports of various domestic mass media, such as the information agency "RosBusinessConsulting", publications "Kommersant", "LIFE", materials from official websites вэб.рф, моногорода.рф, as well as scientific works of domestic authors, devoted to the issue of development of single-industry towns.

When studying this topic, the following were used: private scientific methods: the method of comparative analysis - when studying the goal-setting of programs for the development of single-industry towns, as well as comparing the planned and achieved KPIs of the program "Integrated development of single-industry towns", the method of expert assessments - when analyzing the activities of the Single-Industry Towns Development Fund (SITDF)

\section{Analysis of the development of single-industry towns as a factor of economic regional growth}

Despite the long-term nature of the problem of the development of mono-profile entities, there is no law on single-industry towns in Russia. There is no legislative consolidation of the concept of "single-industry city". This fact causes discrepancies in the number of monoterritories in various sources, which is associated with the method of their selection used in a particular study. In one case, the presence of a city-forming enterprise in the territory is taken into account as a constant, in the other, the prevailing sector of employment, the area of activity of the working population.

1st stage of development of single-industry towns (2008-2014)

The first programs for the development of such territories began to appear in 2000, when single-industry towns began to pose, for the most part, a real threat to national economic security.

Foreign experience in the development of mono-territories has revealed two alternative ways to solve the issue of single-industry towns. The first way is focused on the active 
application of federal and regional state programs for the development of infrastructure of the territory, training of the population in new promising professions, environmental assistance, improving the quality of the road fund, the formation of the attractiveness of the urban environment. The main obstacle in favor of choosing this path is its financial and time costs. The second option is significantly cheaper and focuses on the natural rehabilitation of the territory with minimal involvement of public authorities. The population of the territory is declining due to natural migration, thus eliminating possible social tensions due to high unemployment in the future until the complete closure of the municipality.

Initially, copying foreign experience in the conditions of Russian realities seemed difficult due to the large number of single-industry towns. Focusing on the second option in practice was complicated by the huge scale of the country, the high cost of housing, etc. The first option required modification taking into account geographical and national features. It was conceptually important to resolve the following issues: the restoration of the activities of existing city-forming enterprises, the creation of new jobs to reduce social tension due to a partial or complete suspension of the work of an industrial enterprise, overcoming the mono-profile of the urban economy, modernization of worn-out urban engineering infrastructure, preservation of qualified human capital.

The 2008 global financial crisis brought additional negative prospects to the situation with single-industry towns, which showed the need to take urgent measures in relation to the economies of single-industry cities [3].

The basis in the process of developing an independent model was the program-targeted approach, which evolved into the development of comprehensive investment programs for single-industry cities (CIPs). The process of working on comprehensive investment programs was carried out in 2010-2011 and, according to experts, provided extensive material on single-industry towns, but insufficient for the formation of financial models [4]. However, CIPs: formed a platform for the assessment and development of mono-profile economies; created a system of criteria for programs and projects, implemented in the territories of single-industry towns; provided a trend for the introduction of strategic planning in single-industry towns.

In addition, the development of CIPs allowed to diagnose the mono-profile entities and identified the necessary shortcomings to be eliminated: weak development of small and medium-sized businesses, able to eliminate mono-profile territorial dependence; low quality of transport and engineering infrastructure; underdeveloped housing market within single-industry towns; low wages and obvious lack of interest in solving the problems of mono-territories on the part of regional authorities.

The approbation of complex investment programs made it possible to identify the weak points of their application: short terms for the preparation of programs; insufficient funding and professionalism of management personnel; lack of interconnection of investment projects presented in the CIPs.

The gained experience of strategic planning allowed to formulate priority directions of support of single-industry towns: creation of industrial parks and business incubators for the purpose of development of small and average business as an alternative to the cityforming enterprise; tourism development; reorientation of city-forming enterprises to the production of innovative products.

According to experts [2], the practice of creating industrial parks in solving issues of employment and tourism development turned out to be the most effective for the regions. For mono-formations, industrial parks perform two functions: the economic function helps to develop and introduce new technologies into the production processes of city-forming enterprises; social function generates high quality jobs in the city. Industrial parks have a special potential in small towns, where the functioning of large industrial agglomerations is 
impossible due to the combination of environmental, economic and infrastructural factors. At the same time, the development of adaptive, innovative and knowledge-intensive small and medium-sized businesses is extremely relevant. In domestic practice, there is an "experience in creating" industrial parks both on the basis of an existing city-forming enterprise and completely from scratch [5]. At the same time, given the significant difficulties associated with attracting resources to the economies of mono-territories, the option of organizing a park on the basis of a city-forming enterprise becomes preferable.

Experts refer to the negative factors in the use of industrial parks: an insignificant effect on the existing local labor market in the absence of developed retraining programs for existing specialists; a high percentage of wear and tear of production technological facilities; limited investment resources; environmental pollution.

The issue of developing the economy of mono-profile entities also includes an analysis of a set of financial instruments, mainly aimed at reducing budget expenditures for financing single-territory territories.

Table 1. Financial instruments and applications fields.

\begin{tabular}{|c|c|c|}
\hline Financing field & Financial instruments & Financing goals \\
\hline $\begin{array}{l}\text { Modernization of } \\
\text { housing and } \\
\text { communal services } \\
\text { infrastructure }\end{array}$ & $\begin{array}{l}\text { 1. Standard lending schemes of the } \\
\text { enterprise in case of sufficiency of assets as } \\
\text { collateral. } \\
\text { 2. Third party collateral as well as leasing } \\
\text { instruments are used in case of insufficient } \\
\text { assets. } \\
\text { 3. Bond loans }\end{array}$ & $\begin{array}{c}\text { Reduction of expenses for } \\
\text { complex modernization of } \\
\text { housing and communal } \\
\text { services infrastructure by } \\
7-10 \% \text { with a temporary } \\
\text { payback range of programs } \\
\text { - 5-10 years [6] }\end{array}$ \\
\hline $\begin{array}{l}\text { SME development } \\
\text { (small and medium- } \\
\text { sized enterprises) }\end{array}$ & $\begin{array}{l}\text { 1. Public budget loans and subsidies } \\
\text { 2. Insurance of SME projects. } \\
\text { 3. Interest rate co-financing. } \\
\text { 4. Providing business entities with } \\
\text { marketing information about the state of the } \\
\text { market and its trends }\end{array}$ & $\begin{array}{l}\text { Formation of an effective } \\
\text { model of interaction with } \\
\text { credit and government } \\
\text { institutions in the business } \\
\text { community of mono- } \\
\text { education }\end{array}$ \\
\hline $\begin{array}{l}\text { Development of } \\
\text { import-substituting } \\
\text { industrial } \\
\text { productions }\end{array}$ & $\begin{array}{c}\text { Co-financing for the construction of } \\
\text { technoparks and technology innovation } \\
\text { zones }\end{array}$ & $\begin{array}{l}\text { 1. Reducing the migration } \\
\text { of professionals and youth. } \\
2 \text {. Creation of modern } \\
\text { productions on the basis of } \\
\text { the saved personnel and } \\
\text { scientific base }\end{array}$ \\
\hline Territorial marketing & $\begin{array}{l}\text { The program of social and economic } \\
\text { development with the developed purposes, } \\
\text { tasks, tools and volume of financing for } \\
\text { their realization }\end{array}$ & Investment rating upgrade \\
\hline
\end{tabular}

Other measures of financial support include subsidies for balancing the budgets of the constituent entities of the Russian Federation, subsidizing the costs of legal entities involved in the implementation of investment projects in terms of paying for electricity.

It should be noted that such an approach could not solve the problem of modernization of single-industry towns, a significant part of whose problems lay not exclusively in the financial field.

2nd stage of development of single-industry towns (institutional) (2014-2019)

2014 was the beginning of the second stage of support for single-industry towns. This is due to the emergence of specific institutions, the priority of which was the development of mono-profile territories, where the fundamental role was played by the Single-Industry Towns Development Fund (SITDF) created by Vnesheconombank. The fund mission was 
to develop the infrastructure and diversify mono-profile economies in order to stabilize their economic, social and demographic situation [6], [7]. The tasks of the SITDF were: point investments in projects and infrastructure of single-industry towns; implementation of a "project office" to assist in the development of investment projects, designed to offset the impact of the city-forming enterprise on the urban economy.

Note the logical expediency of the distribution of state priorities in the context of modernization of national economies of the mono-profile type. Worn-out infrastructure of mono-territories is a key barrier to the development of new investment projects there.

SITDF 's five years of experience allow us to draw some preliminary conclusions about its activities. Since its inception, the fund has disbursed 17.76 billion federal funds. According to the Chamber of Accounts, the unemployment rate during the fund's activity in $57.1 \%$ of single-industry towns exceeded the average in Russia, and the number of ablebodied population decreased by 353.6 thousand people [8]. There is a decrease in registered individual entrepreneurs by $68.3 \%$. The fund finances industrial parks with the status of territories of advanced socio-economic development (TOSER) in 65 settlements. At the same time: in $32 \%$ of cases the territories do not have the status of a single-city town, so they cannot be financed from the SITDF; in 74\% of cases, funding was received by mono-profile educations in single-industry towns with high investment attractiveness; the creation of the TOSER was not structured in terms of the tools used due to the location of such territories.

In turn, the Russian government praised the SITDF work and in March 2020 expanded the list of ways to support the fund, adding to the available tools: financing concession projects, lending to leasing companies, co-financing the construction of infrastructure projects in mono-profile entities.

Since 2016, in order to solve the problems of the development of single-industry towns, territories of advanced socio-economic development (TOSER) have been created on their territory. The main goal is the diversification of a mono-profile economy, the need for which is acutely felt by both small and large single-industry towns. At the same time, there is a dependence, which consists in increasing the number of residents, attracted to these territories over the number of people living in the single-industry town [9]. In addition, the stability of the city-forming enterprise has a negative impact on regional diversification processes in a particular single-industry town, which is explained by the indifference to diversification on the part of external investors and local businesses.

The growth of non-fulfillment of the declared indicators by TOSER residents, operating in the territory of mono-profile territories in terms of the volume of attracted investments and the number of jobs created, is a problem today [10]. Note that in some cases, the liquidation of the enterprise is associated with finding a more attractive place to do business, which requires detailed analysis. However, in most cases it is a question of nonfulfillment of the terms of the agreement on granting the status of a TOSER resident.

A separate tool for the development of single-industry towns was the program "Comprehensive development of single-industry towns", which was originally intended to become a large-scale project to modernize mono-profile territories. The program was included in the list of 11 strategic directions for the country's development until 2018 and was focused on accumulating the resources available in the country to reduce unemployment, attracting investment and improving the quality of the urban environment.

The duration of the program was about two years, after which it prematurely ceased to exist in January 2019. 
Table 2. Comparison of planned and achieved KPIs of the program

\begin{tabular}{|c|c|c|}
\hline Indicators & $\begin{array}{c}\text { Planned KPI } \\
\text { programs }\end{array}$ & Achieved results \\
\hline New workplaces & 230 thous. & $406.5 *$ (including temporary) \\
\hline Created by TOSER & 100 & 65 \\
\hline $\begin{array}{c}\text { Number of single-industry } \\
\text { towns }\end{array}$ & Decrease by 18 units & $\begin{array}{c}\text { Increase in the number of crisis single- } \\
\text { industry towns by } 1 / 4 \text { (from 75 to 93) }\end{array}$ \\
\hline
\end{tabular}

*the indicator is not verified, because it cannot be verified according to the data of the Federal Tax Service.

The project "5 steps of Improvement" has become one of the priority indicators of the program "Integrated development of single-industry towns". This project, having highly specialized tasks and limited effect, was a positive experience in the implementation of state crowdfunding, the actors of which were all domestic mono-profile territories. In the process of implementing the project, a unique experience of involving the urban population in solving social problems was formed. In a number of municipalities, whose experience requires special attention, in particular, the city of Kameshkovo in the Vladimir region, by the forces of local authorities, virtually all local residents were involved in the process. In the proposals, special attention was paid to the improvement of squares and sidewalks, sports grounds, parking lots, as well as local ponds and lakes.

\section{3rd stage of development of single-industry towns (2019 — present)}

The third stage in the development of multidisciplinary formations should be considered the early termination of the program for the development of single-industry towns for 20142024 and the development of a new alternative program. The differences in goal setting of the two programs deserve special attention.

Table 3. Goal-setting of development programs for single-industry towns

\begin{tabular}{|c|c|c|}
\hline Goal name & $\begin{array}{l}\text { Formulation of goals in the development } \\
\text { program for single-industry towns for } \\
\text { 2014-2024 }\end{array}$ & $\begin{array}{c}\text { Formulation of goals in the } \\
\text { development program for } \\
\text { single-industry towns for 2019- } \\
2024\end{array}$ \\
\hline New number of jobs & Increase in the number of new jobs & $\begin{array}{l}\text { Increase in the number of new } \\
\text { permanent jobs }\end{array}$ \\
\hline $\begin{array}{l}\text { Citizens' assessment of } \\
\text { the socio-economic } \\
\text { situation in a single- } \\
\text { industry town }\end{array}$ & Not formally taken into account & Taken into account \\
\hline $\begin{array}{l}\text { Attracting investment in } \\
\text { rubles }\end{array}$ & 170 billion & 143.8 billion \\
\hline $\begin{array}{l}\text { Tasks of the Single- } \\
\text { Industry Towns } \\
\text { Development Fund }\end{array}$ & $\begin{array}{l}\text { 1. Formation and training of teams that } \\
\text { implement project management for the } \\
\text { development of mono-education. } \\
\text { 2. Co-financing of expenses of constituent } \\
\text { entities of the Russian Federation and } \\
\text { municipalities in terms of construction and } \\
\text { reconstruction of infrastructure facilities }\end{array}$ & $\begin{array}{l}\text { The same, plus new directions: } \\
\text { 1. Financing of concession } \\
\text { projects. } \\
\text { 2. Issuance of loans to leasing } \\
\text { companies. } \\
\text { 3. Social infrastructure support. }\end{array}$ \\
\hline
\end{tabular}




\section{Conclusions}

The analysis performed allows us to draw the following conclusions and recommendations.

1. By 2020, the institution of state support for single-industry towns, having gone through two stages of evolution, has formed into a system of proven mechanisms and organizational forms for their implementation. The directions of support for single-industry territories have been determined, governing bodies have been created, programs for the development of single-education institutions have been tested and adjusted. Further steps in the development of mono-profile territories are formulated on the basis of available experience.

2. The process of development of mono-territories has passed to the "post-institutional" stage, when the tested efficiency of the established system of institutions of single-industry towns management (SITDF) has been scientifically and socially criticized and today can generate a qualitatively different level of influence on the socio-economic situation of monoprofile cities.

3. When modernizing the approach to the development of monoformations at the third stage, it is important not only to focus on eliminating the "bottlenecks" of previous periods, but also to concentrate on replicating the successful experience of the past. Thus, the creation of a favorable urban environment with the active participation of the local community (Program "5 steps of Improvement") can be extended to other areas aimed at overcoming mono-independence. Otherwise, small victories in the city improvement will be covered by larger manifestations of the "disease" of cities of a single-industry type, which will continue the trend of population migration (especially youth).

4. The process of monitoring the spending of budgetary funds by the Single-Industry Towns Development Fund requires special attention. In particular, the report of the Accounts Chamber on the work of the fund demonstrated inappropriate "expenditures" in the territory with initially high investment attractiveness, as well as in the territories that do not have the status of a single-industry town. In addition, support must be targeted, formed taking into account the personalized business environment in each territory, depending on its specialization.

5. "Human potential" in the development of new projects should be considered as a factor in the innovative development of a single-industry town. Without the creation of permanent innovative jobs with the involvement of the best representatives of the local labor market (at the expense of budget funding), it is impossible to maintain the competitiveness of a mono-profile territory and its survival in the long term. This will entail the loss of the identity of the territory, its cultural code.

6. The current situation with the functioning of the TOSER needs to revise the requirements for residents in terms of reducing the required amount of attracted investments, as well as reducing the number of necessary jobs created. The analysis of the branch component of the activity of TOSER enterprises, concentrated mainly in the production field, deserves special attention, while the efficient economy actively needs the development of the service field as well.

7. The experience demonstrates the impossibility of survival of mono-profile areas alone, in this regard, it is necessary to transfer the coordination of their development in the system to a higher level - federal districts, which will integrate city-forming enterprises into interregional and international distribution chains. This approach will allow to transform the disparate community of single-industry towns into a cluster network with the application of cluster territorial development approaches. 


\section{References}

1. G.V. Kutergina, A.V. Lapin, Perm University Herald, 3(26), 69 (2015)

2. M.S. Oborin, M.Yu. Sheresheva, S.A. Ivanova, E-journal. Public Administration, 68, 211 (2018)

3. S.N. Miroshnikov, E.S. Charkina, ETAP: Economic Theory, Analysis, and Practice, 78 (2018)

4. O.O. Smirnova, Modern Productive Forces, 1, 74 (2015)

5. N.P. Narbut, M.A. Ulyanychev, Humanities, Social-Economic And Social Sciences, 8, 63 (2019)

6. N.E. Popovicheva, A.V. Polyanin, Central Russian Bulletin of Social Sciences, 10 (4), 190 (2015)

7. O.V. Larchenko, Regional Problems Of Economic Transformation, 8, 122 (2019)

8. Official website of the Accounts Chamber of the Russian Federation, https://ach.gov.ru/

9. D. Yu. Faykov, Bulletin of Kemerovo State University, 254 (2019)

10. I.V. Dobrycheva, Herald of Omsk University, 2, 130 (2018) 